\title{
Method of Converting Municipal Proportional Waste Plastics into Liquid Hydrocarbon Fuel by Using Activated Carbon
}

\author{
Moinuddin Sarker*, Mohammad Mamunor Rashid, Mohammed Molla, Muhammad Sadikur Rahman
}

Natural State Research, Inc. Department of Research and Development, 37 Brown House Road (2 ${ }^{\text {nd }}$ Floor), Stamford, CT-06902, USA

\begin{abstract}
The demand for fossil fuel is at an all time high worldwide. Annually 30 billion barrels of petroleum is being consumed worldwide. In this busy society, transportation is vital and, for transportation, petroleum is an obligation. All the major forms of business, agricultural, exports and imports depend on transportation. Transportation requires petroleum to function. Vehicles in the road require fuels, airway transportation requires Aviation fuel and sea transportation requires fuel oil. For not only transportation but also, petroleum is required to make all kind of daily usable plastics. Depletion of petroleum is inevitable at th is current rate of consumption. Emissions released fro m evaporation and co mbustion of these fuel contributes to too many environ mental and health problems; including emitting greenhouse gases that contribute immensely to global warming. Annually $\sim 7$ billion tons of carbon dioxide is released to the environment due to petroleum emission. Moreover, when the plastics are discarded into the landfill, it becomes waste plastic and since plastic is non-biodegradable, it can rema in in the landfill for thousands of year. Waste plastics presence in the landfill causes environmental problems e.g., it can cause soil to decay. Alternative source of energy created from Solar, W ind, Hydrogen Fuel, Bio mass Fuel, Bio-Diesel, Green Diesel, Bio-ethanol, and Geo-thermal has been proposed as a solution to these problems. A developed process of thermally breaking down the hydrocarbon of chains of plastic has been studied and implemented to produce a liquid fuel in the presence of activated carbon. The activated carbon acts as a filter to absorb dye from the waste plastic during the thermal process to increase the quality of the final product. This fuel can be used for all kinds of transportation, and will emit much less emission compared to the current commercial fuel and it will be cost effective.
\end{abstract}

Keywords Waste Plastic, Fuel, Activated Carbon, Thermal, GC/MS, FT-IR

\section{Introduction}

In recent years the production and consumption of plastics have increased drastically; as a consequence the responsible disposal of plastic wastes has created serious social and environmental arguments. At present both land filling and incineration of plastic wastes are widely practiced. In Japan, the percentage of municipal plastic wastes, as a fraction of municipal solid waste (MSW), that was land filled in the early 1980 s was estimated to be $45 \%$, incineration was $50 \%$, and the other $5 \%$ was subjected to separation and recycling[1]. In the USA, more than $15 \%$ of the total MSW was incinerated in 1990; only about $1 \%$ of post-consumer plastics were recycled[2-4]. Land filling of plastic wastes is expected to decrease in the future as landfillspace is depleted and plastic wastes are resistant to environmental degradation. Co-incineration of plastic wastes with other municipal solid

* Corresponding author:

msarker@naturalstat eres earch.com (Moinuddin Sarker)

Published online at http://journal.sapub.org/ijmc

Copyright (C) 2012 Scientific \& Academic Publishing. All Rights Reserved wastes may be increasingly practiced, because the high caloric value of plastics can enhance the heating value of MSW and facilitate an efficient incineration, while their energy content can also be recovered. But the potential relationship between plastics fed into an incinerator and the formation of some highly toxic pollutants such as dioxins and furans is still unclear. It has been suggested that the chlorine content in PVC and other plastics is related to the formation of dioxins and furans, which are chlorinated polynuclear aromatic compounds. And although there is considerable evidence that these pollutants would still be generated in the absence of plastics, environmental pressures against incineration have never completely disappeared.

Plastic wastes can be classified as industrial and municipal plastic wastes according to their origins; these groups have different qualities and properties and are subjected to different management strategies. Industrial plastic wastes are those arising from the plastics manufacturing and processing industry. Usually they are homogeneous or heterogeneous plastic resins, relatively free of contamination and available in fairly large quantities. Recycling technologies for industrial plastic wastes are currently based on pelletization 
and mold ing into low grade plastic products; the recycled products have poor mechanical and color qualities and a lower market value[5]. The reclaimed product outputs of Japan in the early 1980 s already amounted to some $15 \%$ of total industrial plastic wastes[1]. Thus for industrial plastic wastes, repelletization and remolding seem to be a simple and effective means of recycling. But when plastic wastes are heterogeneous or consist of mixed resins, they are unsuitable for reclamation. In this case thermal cracking into hydrocarbons may provide a suitable means of recycling, which is termed chemical recycling. Municipal plastic wastes normally remain a part of municipal solid wastes as they are discarded and collected as household wastes. Plastics usually account for about $7 \%$ of the total MSW by weight and much more by volume. In order to recycle municipal plastic wastes, separation of plastics from other household wastes is required. Although MSW separation technologies have been studied extensively, it is still not possible to classify MSW mechanically and obtain marketable fractions. If household wastes are separately disposed into three parts: (1) combustibles such as paper, kitchen waste, textiles, and wood, (2) inco mbustibles such as metals, glass, ceramics, and (3) plastics, then the collected plastics will be mixed plastic wastes with major components ofPE, PP, PS, PVC, etc. For mixed plastics some mechanical separation equipment is currently available[1, 6]. For example, using a wet separation process mixed plastics can be separated into two groups: those with a density greater than water such as PS and PVC, and those with a density lower than that of water such as PE, PP and expanded PS. The latter group is much larger than the first group. Consequently, recycling of mun icipal plastic wastes should deal with plastic mixtures of low and high PE, PP and PS, provided that the above separation procedures are practiced. Typical composition of such plastic mixture will be three parts PE, one part PP and one part PS. More investigations are needed to identify the sources and properties of plastic wastes, and their suitability for various recycling methods such as repelletization, remolding and pyrolysis [7]. Some other research group also performed with plastic to fuel production process with thermal degradation or thermal cracking process [8-10], catalytic cracking process[11-13], pyrolysis process[14-15] and kinetic method[16] also applied for plastic to fuel energy conversion process. Natural state research, Inc uses thermal degradation process to convert industrial and municipal waste mixture plastics to hydrocarbon liquid fuel. Activated carbon was added as a dye removing purposes because it's removed the different color dyes of plastics from fuel products. As a result fuel color co mes clear and transparent.

\section{Experimental Section}

\subsection{Material}

Waste plastics raw materials collected from local area grocery stores and coffee shops. The waste plastics collected comes with foreign materials such as paper, sand, food, coffee, insect etc. After collection waste plastic are separated out of all foreign material. Waste plastic components are a mixtu re of white co lor milk containers, red co lor coffee cups, transparent food containers, black color food containers and some different color shopping bags. Separated waste plastics are washed with liquid soap and dried in room temperature. During the washing period of the waste plastics a considerable amount of waste water is generated. The waste water is kept into a separate container for waste water treatment. The waste water is treated with acidic and alkali method with coagulation and flocculation process. For the waste water treatment process potash alum and sodium hydroxide solution with different normality is used.

\subsection{Sample Preparation and Pre-analysis}

Wash plastics are cut into small pieces, $\sim 3-4$ inch $^{2}$ using scissor. The small pieces of plastics are put into the grinder mach ine and grounded into $2-3 \mathrm{~mm}$ pieces. Grounded plastic mixed with ratio wise equally. Four category of waste plastic (HDPE, LDPE, PP \& PS) was uses for the liquefaction process and ratio was $25 \%$ each sample by weight. The raw materials were analysed by using Perkin Elmer GC/MS with pyroprobe for solid materials and solid sample volatile temperature with pyroprobe $1200^{\circ} \mathrm{C}$. GC and $\mathrm{MS}$ result showed raw materials compound structure and FTIR was use for materials functional group and functional group wave band energy. TGA (Pyris-1) was used for materials onset temperature which was representing liquefaction average temperature.

\subsection{Experimental Process}

Plastic to fuel production process into laboratory scale was use thermal degradation at temperature $25-420{ }^{\circ} \mathrm{C}$ under atmospheric pressure and under fume hood. For the experiment 1 kilogram of sample was used in a 316 stainless steel reactor. Reactor temperature can range up to $500{ }^{\circ} \mathrm{C}$. $25 \%$ LDPE, $25 \%$ HDPE, $25 \%$ PP and $25 \%$ PS with $5 \%$ activated carbon in a fully closed system. Waste plastic sample were put into the reactor chamber with activated carbon and heating started from room temperature up to 420 ${ }^{\circ} \mathrm{C}$. When the plastics started to melt as temperature was increased vapor started to form inside the reactor, the vapor then passes through a condenser unit. The condensation of the vapor becomes liquid in a form called plastic fuel (See fig. 1). This waste plastic to fuel conversion rate is $89 \%$. This produced fuel density is $0.78 \mathrm{~g}$. $/ \mathrm{ml}$. No catalyst and no extra chemical used in this conversion process because already metal content are present in the plastic raw materials. Those metal contents act as a catalyst for breaking down long chain hydrocarbon to short chain hydrocarbon during the thermal degradation process. During plastic convert to fuel all vapor are not turn into fuel some vapor portion is come out as a light gas because gas boiling point is minus temperature. To clean the light gas $\left(\mathrm{C}_{1}-\mathrm{C}_{4}\right)$ a $0.5(\mathrm{~N}) \mathrm{NaOH} / \mathrm{NaHCO}_{3}$ and 
after alkali wash light gases passing through also water wash and at the end we put light gas into gas storage tank by using small pump. This light gas percentage is $7 \%$. The produced plastic fuelpasses through RCI fuel purification unit due to centrifugal force fuel making clean and water and sediment come out separately its call fuel sediment, this sediment and water we can retreat. Activated carbon was added in the process to remove plastic dye because during the production period plastic industries use about 3\% additive for different shape or model and that dye affects the quality of the end product. The activated carbon filters the heavy contents of the dye and neutralizes them during the thermal degradation process. Waste plastic to fuel production period some black solid residue is generated from the plastics. This residue amount is about $4 \%$. This solid residue has good Btu value and experiment run time was 4.50 hours.

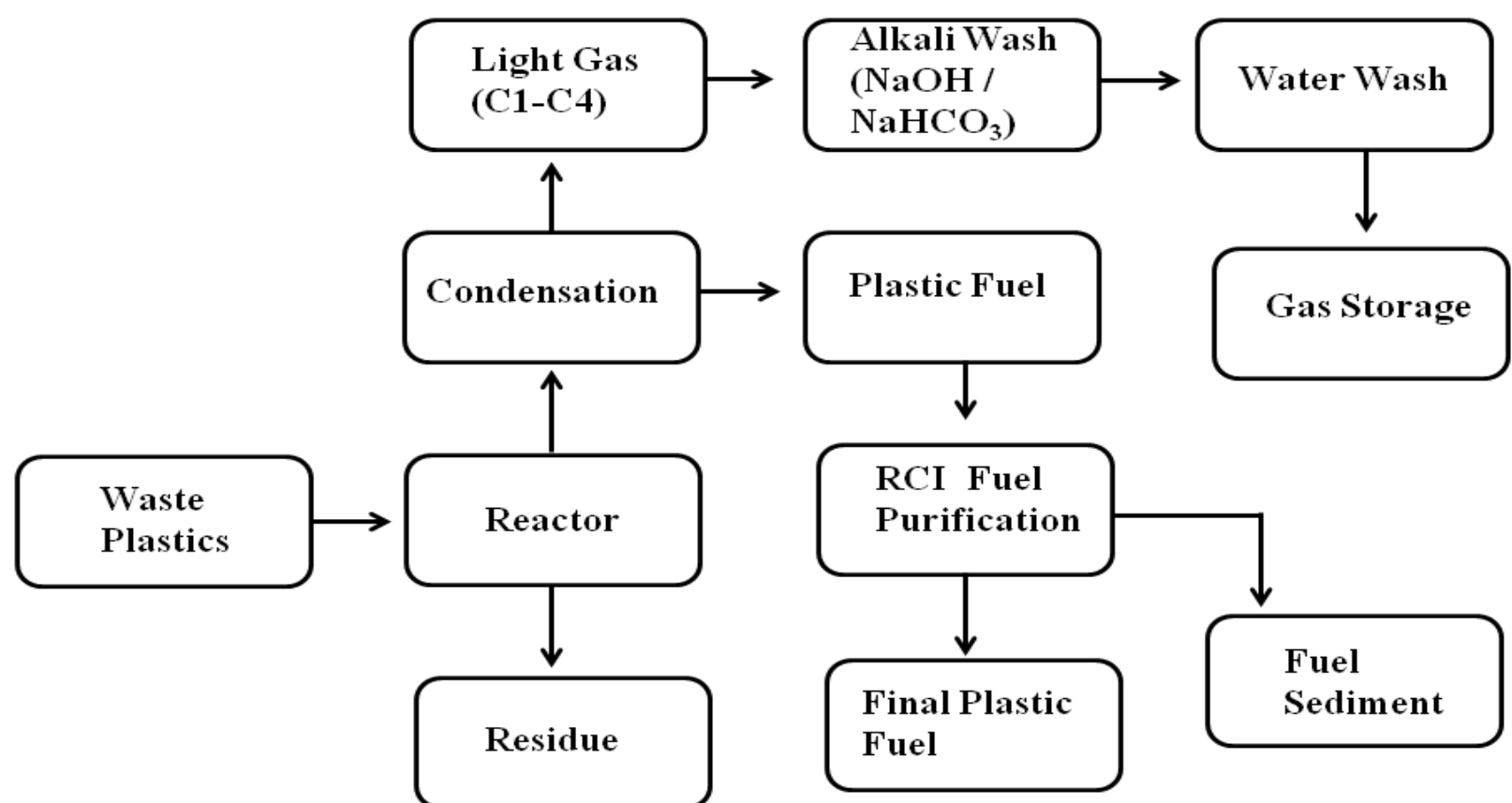

Figure 1. Proportional waste plastic into fuel production process

Table 1. HDPE, LDPE, PP and PS waste plast ic trace metal data

\begin{tabular}{|c|c|c|c|c|c|}
\hline $\begin{array}{l}\text { Name of Test } \\
\text { Method }\end{array}$ & Name of Metal & $\begin{array}{c}\text { HDPE } \\
\text { (White Color) ppm }\end{array}$ & $\begin{array}{c}\text { LDPE } \\
\text { (Red Color) ppm }\end{array}$ & $\begin{array}{c}\text { PP (Tran sparent) } \\
\text { ppm }\end{array}$ & $\begin{array}{c}\text { PS } \\
\text { (Red Color) } \\
\text { ppm }\end{array}$ \\
\hline \multirow[t]{22}{*}{ AST M D1976 } & Silver & $<1.0$ & $<1.0$ & $<1.0$ & $<1.0$ \\
\hline & Aluminium & 130.0 & 197.4 & $<1.0$ & 59.8 \\
\hline & Boron & $<1.0$ & 2.8 & $<1.0$ & 2.8 \\
\hline & Barium & $<1.0$ & $<1.0$ & $<1.0$ & 2.7 \\
\hline & Calcium & 452.1 & 962.6 & 30.5 & 33420 \\
\hline & Chromium & $<1.0$ & $<1.0$ & $<1.0$ & $<1.0$ \\
\hline & Copper & $<1.0$ & $<1.0$ & $<1.0$ & $<1.0$ \\
\hline & Iron & 20.3 & 6.0 & 3.9 & 47.2 \\
\hline & Potassium & $<1.0$ & 35.4 & $<1.0$ & 28.4 \\
\hline & Lithium & $<1.0$ & $<1.0$ & $<1.0$ & 16.8 \\
\hline & Magnesium & 15.2 & 25.1 & 2.8 & 842.7 \\
\hline & Molybdenum & $<1.0$ & $<1.0$ & $<1.0$ & $<1.0$ \\
\hline & Sodium & 23.4 & 45.2 & 5966 & 118.8 \\
\hline & Nickel & $<1.0$ & $<1.0$ & $<1.0$ & $<1.0$ \\
\hline & Phosphorus & 39.3 & 26.7 & $<1.0$ & $<1.0$ \\
\hline & Lead & $<1.0$ & $<1.0$ & $<1.0$ & $<1.0$ \\
\hline & Antimony & $<1.0$ & $<1.0$ & $<1.0$ & $<1.0$ \\
\hline & Silicon & 104.2 & 90.2 & 5.3 & 17.2 \\
\hline & Tin & $<1.0$ & $<1.0$ & $<1.0$ & $<1.0$ \\
\hline & Titanium & 2.2 & 2.7 & $<1.0$ & 60.8 \\
\hline & Vanadium & $<1.0$ & $<1.0$ & $<1.0$ & $<1.0$ \\
\hline & Zinc & 2.2 & 2.6 & $<1.0$ & 89.9 \\
\hline
\end{tabular}




\section{Results and Discussion}

\subsection{Analysis Technique}

For analys is purpose a GC column was use (Perkin Elmer) with a elite-5MS length 30 meter, $0.25 \mathrm{~mm}$ ID, $0.5 \mathrm{um} \mathrm{df}$, maximum program temperature $350^{\circ} \mathrm{C}$ and minimum bleed at $330^{\circ} \mathrm{C}$ (cat.\# N9316284) and also it can be used $-60^{\circ} \mathrm{C}$. Capillary column internal silica coating of viscous liquid such as carbowax or wall bonded organic materials. GC/MS operational purpose was used carrier gas as Helium gas. For GC method setup init ial te mperature $40^{\circ} \mathrm{C}$ and in itial hold for 1 minute. Final temperature setup is $330^{\circ} \mathrm{C}$. Temperature ramping rate is $10^{\circ} \mathrm{C} /$ minutes up to $325^{\circ} \mathrm{C}$ and hold for 15 minutes $325{ }^{\circ} \mathrm{C}$. Total experiment runs time 44.50 minutes. MS method setup for sample analysis MS scan time 1 to 44.50 minutes and mass detection 35- $528 \mathrm{EI}+$ centroid. Internal scan time used 0.15 second. Mass detection is creating $\mathrm{m} / \mathrm{z}$ ratio. FT-IR analys is purpose used Perkin Elmer FT-IR spectrum 100, range $4000-400 \mathrm{~cm}^{-1}$, number of scan 32 and resolution 4 . $\mathrm{NaCl}$ cell was used as a fuel sample holder. $\mathrm{NaCl}$ cell thickness is $0.05 \mathrm{~mm}$. Liquid fuel analys is by Perkin Elmer DSC and analys is purpose used temperature $5-400^{\circ} \mathrm{C}$, ramping rate $10^{\circ} \mathrm{C} / \mathrm{min} .50$ micro liter aluminium pan us ed for sample holding and nitrogen gas us ed for carrier. TGA (Pyris-1) was used raw sample analys is and by TGA can measurement raw sample onset temperature. Temperature profile was use for raw sample analys is $50-800$ ${ }^{\circ} \mathrm{C}$ and ramping rate was $10^{\circ} \mathrm{C} / \mathrm{min}$. Helium gas was use as carrier gas.

\subsection{Raw Material Analysis Result}

ICP (Inductively coupled plasma atomic emission spectroscopy) analys is results showed (table 1) waste plastic has different category of metal present into raw material in ppm level. All metal comes from the plastic manufacture period when different kind of additives and catalyst are added for better quality and shape. Some research study indicates that waste plastic has different kind of additives. Plastics are manufactured by polymerization, polycondensat ion, or polyaddition reactions wheremonomeric molecules are joined sequentially under controlled conditions to produce high-molecular-weight polymers whose basic properties are defined by their composition, molecular weight distribution, and their degree of branching or cross-lin king. To control the polymerization process, a broad range of structurally specific proprietary chemical compounds is used for polymerization initiation, breaking, and cross-linking reactions (peroxides, Ziegler-Natta, and metallocene catalysts). The polymerized materials are admixed with proprietary antioxidants (sterically hindered phenols, organophosphites), UV and light stability improvers (hindered amines and piperidyl esters), antistatic agents (ethoxy lated amines), impact modifiers (methacrylat ebutadiene-styrene compounds), heat stabilizers (methyl tin mercaptides), lubricants (esters), biostabilizers (arsine, thiazoline, and phenol compounds), and plasticizers used to modify the plasticity, softness, and pliability of plastics (phthalates and esters)[17]. For that reason waste plastics conversion into fuel doesn't need any kind of catalyst. Without catalyst waste plastic can conversion into fuel by using this technology.

Table 2. Raw Materials Waste Plastic CHN\% by EA-2400 (CHN Mode)

\begin{tabular}{ccccc}
\hline $\begin{array}{c}\text { Name of } \\
\text { Method }\end{array}$ & $\begin{array}{c}\text { Name } \\
\text { of } \\
\text { Waste } \\
\text { Plastic }\end{array}$ & Carbon \% & Hydrogen \% & Nitrogen \% \\
\hline ASTM & HDPE & 83.57 & 14.78 & $<0.30$ \\
D5291.a & LDE & 85.33 & 14.31 & $<0.30$ \\
& PP & 79.93 & 14.17 & $<0.30$ \\
& PS & 78.60 & 7.21 & $<0.30$ \\
\hline
\end{tabular}

EA-2400 material analysis result indicate that $\mathrm{C}, \mathrm{H}, \mathrm{N}$ percentages are present into raw materials shown table 2 . TGA (Pyris-1) raw materials analysis result showed HDPE waste plastic inflection point temperature $430.98{ }^{\circ} \mathrm{C}$ and onset temperature $420.65^{\circ} \mathrm{C}$, LDPE waste plastic inflection temperature $457.11^{\circ} \mathrm{C}$ and ons et temperature $421.53{ }^{\circ} \mathrm{C}$, PP waste plastic inflection temperature $403.72{ }^{\circ} \mathrm{C}$ and onset temperature $359.63{ }^{\circ} \mathrm{C}$ and PS waste plastic inflection temperature $364.88^{\circ} \mathrm{C}$ and onset temperature $326.62^{\circ} \mathrm{C}$.

\subsection{Liquid Fuel Analysis}

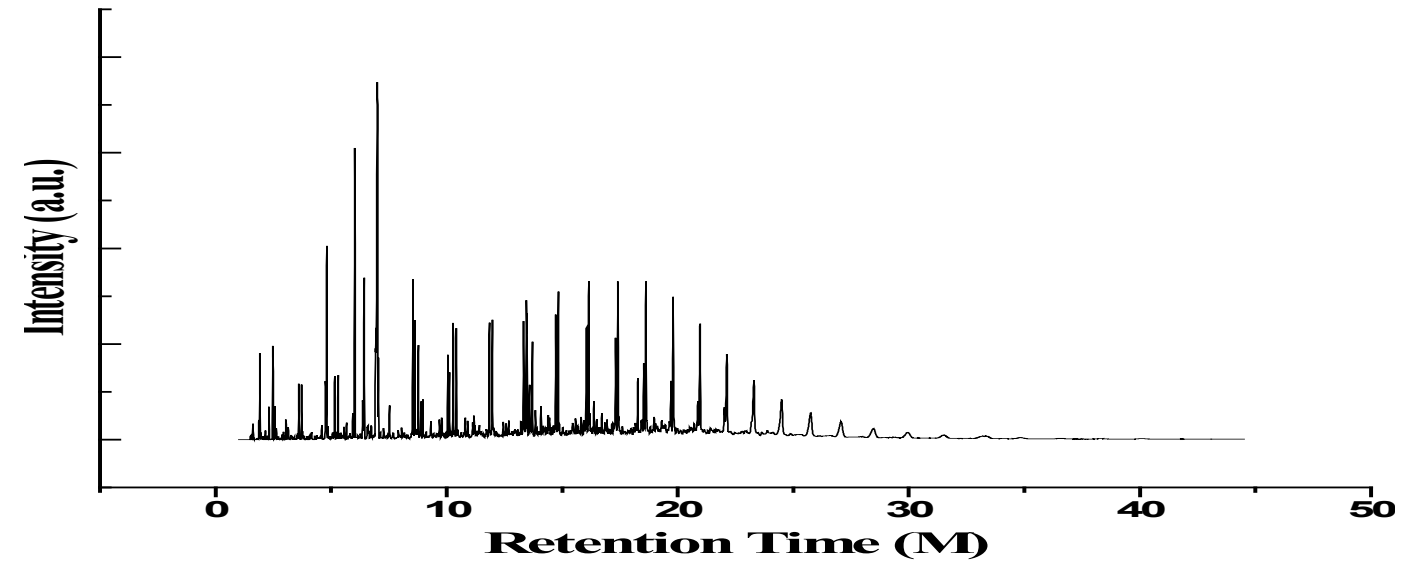

Figure 2. GC/MS chromat ogram of proportional waste plastic into fuel 
Liquid Hydrocarbon Fuel by Using Activated Carbon

Table 3. GC/MS chromatogram of proportional waste plast ic into fuel compound list

\begin{tabular}{|c|c|c|c|c|}
\hline Number of Peak & $\begin{array}{l}\text { Retention Time } \\
\text { (min.) }\end{array}$ & $\begin{array}{l}\text { Compound } \\
\text { Name }\end{array}$ & $\begin{array}{l}\text { Compound } \\
\text { Formula }\end{array}$ & $\begin{array}{l}\text { Mole cular } \\
\text { Weight }\end{array}$ \\
\hline 1 & 1.51 & Propane & $\mathrm{C}_{3} \mathrm{H}_{8}$ & 44 \\
\hline 2 & 1.61 & 1-Propene, 2-methyl- & $\mathrm{C}_{4} \mathrm{H}_{8}$ & 56 \\
\hline 3 & 1.91 & Pentane & $\mathrm{C}_{5} \mathrm{H}_{12}$ & 72 \\
\hline 4 & 2.31 & Pentane, 2-methyl- & $\mathrm{C}_{6} \mathrm{H}_{14}$ & 86 \\
\hline 5 & 2.48 & 1-Pentene, 2-methyl- & $\mathrm{C}_{6} \mathrm{H}_{12}$ & 84 \\
\hline 6 & 2.56 & Hexane & $\mathrm{C}_{6} \mathrm{H}_{14}$ & 86 \\
\hline 7 & 3.05 & 1-Pentene, 2,4-dimethyl- & $\mathrm{C}_{7} \mathrm{H}_{14}$ & 98 \\
\hline 8 & 3.14 & 2,4-Dimethyl 1,4-pentadiene & $\mathrm{C}_{7} \mathrm{H}_{12}$ & 96 \\
\hline 9 & 3.60 & 1-Heptene & $\mathrm{C}_{7} \mathrm{H}_{14}$ & 98 \\
\hline 10 & 3.72 & Heptane & $\mathrm{C}_{7} \mathrm{H}_{16}$ & 100 \\
\hline 11 & 4.55 & Cyclobutane, (1-methylethylidene)- & $\mathrm{C}_{7} \mathrm{H}_{12}$ & 96 \\
\hline 12 & 4.60 & 1-Heptene, 4-methyl- & $\mathrm{C}_{8} \mathrm{H}_{16}$ & 112 \\
\hline 13 & 4.81 & Toluene & $\mathrm{C}_{7} \mathrm{H}_{8}$ & 92 \\
\hline 14 & 5.15 & 1-Octene & $\mathrm{C}_{8} \mathrm{H}_{16}$ & 112 \\
\hline 15 & 5.30 & Octane & $\mathrm{C}_{8} \mathrm{H}_{18}$ & 114 \\
\hline 16 & 5.94 & Cyclohexane, 1,3,5-trimethyl- & $\mathrm{C}_{9} \mathrm{H}_{18}$ & 126 \\
\hline 17 & 6.02 & 2,4-Dimethyl-1-heptene & $\mathrm{C}_{9} \mathrm{H}_{18}$ & 126 \\
\hline 18 & 6.43 & Ethylbenzene & $\mathrm{C}_{8} \mathrm{H}_{10}$ & 106 \\
\hline 19 & 7.00 & 1,3,5,7-Cyclooctat etraene & $\mathrm{C}_{8} \mathrm{H}_{8}$ & 104 \\
\hline 20 & 7.52 & Benzene, (1-methylethyl)- & $\mathrm{C}_{9} \mathrm{H}_{12}$ & 120 \\
\hline 21 & 8.05 & Benzene, propyl- & $\mathrm{C}_{9} \mathrm{H}_{12}$ & 120 \\
\hline 22 & 8.54 & $\alpha$-Methylstyrene & $\mathrm{C}_{9} \mathrm{H}_{10}$ & 118 \\
\hline 23 & 8.63 & 1-Decene & $\mathrm{C}_{10} \mathrm{H}_{20}$ & 140 \\
\hline 24 & 8.77 & Decane & $\mathrm{C}_{10} \mathrm{H}_{22}$ & 142 \\
\hline 25 & 8.89 & Octane, 3,3-dimethyl- & $\mathrm{C}_{10} \mathrm{H}_{22}$ & 142 \\
\hline 26 & 9.31 & Benzene, 1-propenyl- & $\mathrm{C}_{9} \mathrm{H}_{10}$ & 118 \\
\hline 27 & 9.69 & 2-Undecanethiol, 2-methyl- & $\mathrm{C}_{12} \mathrm{H}_{26} \mathrm{~S}$ & 202 \\
\hline 28 & 9.79 & $\begin{array}{l}\text { Bicyclo[3.1.0]hex-3-en-2-ol, } \\
\text { 2-methyl-5-(1-methylethyl)-, }(1 \alpha, 2 \alpha, 5 \alpha) \text { - }\end{array}$ & $\mathrm{C}_{10} \mathrm{H}_{16} \mathrm{O}$ & 152 \\
\hline 29 & 10.05 & Cyclooctane, 1,4-dimethyl-,trans- & $\mathrm{C}_{10} \mathrm{H}_{20}$ & 140 \\
\hline 30 & 10.28 & 1-Undecene & $\mathrm{C}_{11} \mathrm{H}_{22}$ & 154 \\
\hline 31 & 10.42 & Undecane & $\mathrm{C}_{11} \mathrm{H}_{24}$ & 156 \\
\hline 32 & 11.13 & Benzene, (3-methyl-3-butenyl)- & $\mathrm{C}_{11} \mathrm{H}_{14}$ & 146 \\
\hline 33 & 11.18 & $(2,4,6$-T rimethylcyclohexyl) methanol & $\mathrm{C}_{10} \mathrm{H}_{20} \mathrm{O}$ & 156 \\
\hline 34 & 11.85 & 1-Dodecene & $\mathrm{C}_{12} \mathrm{H}_{24}$ & 168 \\
\hline 35 & 11.98 & Dodecane & $\mathrm{C}_{12} \mathrm{H}_{26}$ & 170 \\
\hline 36 & 12.43 & Decane, 2,3,5,8-tetramethyl- & $\mathrm{C}_{14} \mathrm{H}_{30}$ & 198 \\
\hline 37 & 12.69 & 2-Hexyl-1-octanol & $\mathrm{C}_{14} \mathrm{H}_{30} \mathrm{O}$ & 214 \\
\hline 38 & 13.33 & 1-Tridecene & $\mathrm{C}_{13} \mathrm{H}_{26}$ & 182 \\
\hline 39 & 13.45 & Tridecane & $\mathrm{C}_{13} \mathrm{H}_{28}$ & 184 \\
\hline 40 & 13.71 & 1-Decanol, 2-hexyl- & $\mathrm{C}_{16} \mathrm{H}_{34} \mathrm{O}$ & 242 \\
\hline 41 & 14.08 & Trichloroacetic acid, hexadecyl ester & $\mathrm{C}_{18} \mathrm{H}_{33} \mathrm{Cl}_{3} \mathrm{O}_{2}$ & 386 \\
\hline 42 & 14.72 & 1-Tetradecene & $\mathrm{C}_{14} \mathrm{H}_{28}$ & 196 \\
\hline 43 & 14.83 & Tetradecane & $\mathrm{C}_{14} \mathrm{H}_{30}$ & 198 \\
\hline 44 & 15.82 & Benzeneacetic acid, 4-pentadecyl ester & $\mathrm{C}_{23} \mathrm{H}_{38} \mathrm{O}_{2}$ & 346 \\
\hline 45 & 16.05 & 1-Pentadecene & $\mathrm{C}_{15} \mathrm{H}_{30}$ & 210 \\
\hline 46 & 16.15 & Pentadecane & $\mathrm{C}_{15} \mathrm{H}_{32}$ & 212 \\
\hline 47 & 16.37 & Trichloroacetic acid, hexadecyl ester & $\mathrm{C}_{18} \mathrm{H}_{33} \mathrm{Cl}_{3} \mathrm{O}_{2}$ & 386 \\
\hline 48 & 17.31 & 1-Hexadecene & $\mathrm{C}_{16} \mathrm{H}_{32}$ & 224 \\
\hline 49 & 17.41 & Hexadecane & $\mathrm{C}_{16} \mathrm{H}_{34}$ & 226 \\
\hline 50 & 18.27 & Benzene, 1,1'-(1,3-propanediyl) bis- & $\mathrm{C}_{15} \mathrm{H}_{16}$ & 196 \\
\hline 51 & 18.53 & 3-Heptadecene, $(Z)-$ & $\mathrm{C}_{17} \mathrm{H}_{34}$ & 238 \\
\hline 52 & 18.62 & Heptadecane & $\mathrm{C}_{17} \mathrm{H}_{36}$ & 240 \\
\hline 53 & 18.98 & 1-Hexadecanol, 2-methyl- & $\mathrm{C}_{17} \mathrm{H}_{36} \mathrm{O}$ & 256 \\
\hline 54 & 19.71 & E-15-Heptadecenal & $\mathrm{C}_{17} \mathrm{H}_{32} \mathrm{O}$ & 252 \\
\hline 55 & 19.80 & Octadecane & $\mathrm{C}_{18} \mathrm{H}_{38}$ & 254 \\
\hline 56 & 20.87 & 9-Nonadecene & $\mathrm{C}_{19} \mathrm{H}_{38}$ & 266 \\
\hline 57 & 20.97 & Nonadecane & $\mathrm{C}_{19} \mathrm{H}_{40}$ & 268 \\
\hline 58 & 22.02 & 1-Eicosene & $\mathrm{C}_{20} \mathrm{H}_{40}$ & 280 \\
\hline 59 & 22.12 & Eicosane & $\mathrm{C}_{20}{ }_{0} \mathrm{H}_{42}$ & 282 \\
\hline 60 & 23.30 & Heneicosane & $\mathrm{C}_{2 .} \mathrm{H}_{44}$ & 296 \\
\hline 61 & 25.75 & Octacosane & $\mathrm{C}_{28} \mathrm{H}_{58}$ & 394 \\
\hline 62 & 27.06 & Heptacosane & $\mathrm{C}_{27} \mathrm{H}_{56}$ & 380 \\
\hline
\end{tabular}


Waste plastic to produced fuel analysed by gas chromatography and mass spectrometer (GC/MS) seen fig.2 and table 3. GC-MS analysis of proportionally mixture of HDPE, LDPE, PP \& PS plastics to fuel in order to measure retention time and molecular weight numerous aliphatic, aromatic derivatives and different types of hydrocarbon compounds and hydrocarbon chain ranges $C_{3}$ to $C_{28}$. At the initial stage of the analysis phases at retention time and molecular weight 44, compound is Propane $\left(\mathrm{C}_{3} \mathrm{H}_{8}\right)$, retention time 1.61 and molecular weight 56 , and compound is 1-Propene, 2-methyl- $\left(\mathrm{C}_{4} \mathrm{H}_{8}\right)$, retention time 1.91 and molecular weight 72 , compound is Pentane $\left(\mathrm{C}_{5} \mathrm{H}_{12}\right)$, retention time 2.31 and molecular weight 86 , functional group is Pentane-2-methyl- $\left(\mathrm{C}_{6} \mathrm{H}_{14}\right)$, retention time 2.48 and molecular weight 84 , functional group is 1-Penetene-2-methyl- $\left(\mathrm{C}_{6} \mathrm{H}_{12}\right)$, retention time 2.56 and molecular weight is 86 , compound is Hexane, $\left(\mathrm{C}_{6} \mathrm{H}_{14}\right)$, retention time 3.05 and molecular weight 98 ,compopund is 1-Pentene-2,4-dimethyl- $\left(\mathrm{C}_{7} \mathrm{H}_{14}\right)$, retention time 3.72 and mo lecular weight 100 , compound is $\left(\mathrm{C}_{7} \mathrm{H}_{16}\right)$, retention time 4.55 ,molecular weight 96, compound is Cyclobutane, (1-methylethylidene)- $\left(\mathrm{C}_{7} \mathrm{H}_{12}\right)$,retention time 4.60 and mo lecular weight 112 , compound is 1 -Heptene, 4 - methyl$\left(\mathrm{C}_{8} \mathrm{H}_{16}\right)$, retention time 4.81 and molecular weight 92 ,compound is Toluene $\left(\mathrm{C}_{7} \mathrm{H}_{8}\right)$, retention time 5.15 and molecular weight 112 ,compound is 1 -Octene $\left(\mathrm{C}_{8} \mathrm{H}_{16}\right)$ etc. In the middle phase of the analys is index in according with the retention time and molecular weight also different types of compound is appeared. According to the their retention time and molecular weight such as retention time 6.02 and mo lecular weight 126 , compound is 2, 4-dimethyl-1-heptene $\left(\mathrm{C}_{9} \mathrm{H}_{18}\right)$, retention time 7.52 and molecular weight 120 , compound is Benzene, (1-methylethyl)- $\left(\mathrm{C}_{9} \mathrm{H}_{112}\right)$, retention time 8.89 and molecular weight 142, compound is Octane,3,3-dimethyl- $\left(\mathrm{C}_{10} \mathrm{H}_{22}\right)$,retention time 9.79 and molecular weight 152, compound is Bicyclo[3.1.0]

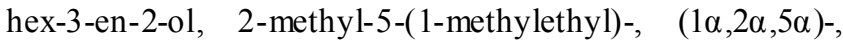
$\left(\mathrm{C}_{10} \mathrm{H}_{16} \mathrm{O}\right)$,retention time 10.05 and molecular weight 140 , compound is Cyclooctane, 1,4-dimethyl-, trans-( $\left.\mathrm{C}_{10} \mathrm{H}_{20}\right)$, retention time 10.28 and molecular weight and molecular weight 154,compound is 1-Undecene $\left(\mathrm{C}_{11} \mathrm{H}_{22}\right)$, retention time 10.42 and molecular weight 156 , compound is Undecane, ( $\mathrm{C}_{11} \mathrm{H}_{24}$ ), retention time 11.13 and molecular weight 146, compound is Benzene, (3-methyl-3-butenyl)-,( $\mathrm{C}_{11} \mathrm{H}_{14}$ ), retention time 11.18 and molecular weight 156 , compound is $(2,4,6-$ Trimethylcyclohexyl) methanol $\left(\mathrm{C}_{10} \mathrm{H}_{20} \mathrm{O}\right)$, retention time 11.85 and molecular weight 168 , compound is 1 -Dodecene $\left(\mathrm{C}_{12} \mathrm{H}_{24}\right)$, retention time 11.98 and molecular weight 170 , compound is Dodecane $\left(\mathrm{C}_{12} \mathrm{H}_{26}\right)$ as well as retention time 12.43 and molecular weight 198 , compound is Decane, 2,3,5,8-tetramethyl-, $\left(\mathrm{C}_{14} \mathrm{H}_{30}\right)$, retention time 12.69 and molecular weight 214 , compound is 2-Hexy1-1-octanol-, $\left(\mathrm{C}_{10} \mathrm{H}_{16} \mathrm{O}\right)$, retention time 13.33 and molecular weight 182 ,compound is 1 -Tridecene, $\left(\mathrm{C}_{13} \mathrm{H}_{26}\right)$, retention time 13.45 and molecular weight 184 , compound is Tridecane $\left(\mathrm{C}_{13} \mathrm{H}_{28}\right)$, retention time 13.71 and molecular weight 242 , compound is 1-Decanol-2-hexyl- $\left(\mathrm{C}_{10} \mathrm{H}_{16} \mathrm{O}\right)$, retention time 14.72 and molecular weight 196 , compound is 1-Tetradecene, $\left(\mathrm{C}_{14} \mathrm{H}_{28}\right)$, retention time 14.83 and molecular weight 198 , compound is Tetradecane, $\left(\mathrm{C}_{14} \mathrm{H}_{30}\right)$, retention time 16.05 and molecular weight 210,compound is 1-Pentadecene, $\left(\mathrm{C}_{15} \mathrm{H}_{30}\right)$ etc. In the end phase of the analys is index in according to retention time and molecular weight several compounds are emerged. However in accordance to retention time 16.37 and molecular weight 212 , compound is Pentadecane, $\left(\mathrm{C}_{15} \mathrm{H}_{32}\right)$, retention time 16.37 and molecular weight 386,compound is Trichloroacetic acid, hexadecyl ester $\left(\mathrm{C}_{18} \mathrm{H}_{33} \mathrm{C}_{13} \mathrm{O}_{2}\right)$, retention time 17.41 and molecular weight 226, compound is Hexadecane, $\left(\mathrm{C}_{16} \mathrm{H}_{34}\right)$, retention time 18.98 and molecular weight 256, compound is 1-Hexadecanol,2-mehtyl- $\left(\mathrm{C}_{17} \mathrm{H}_{36} \mathrm{O}\right)$, retention time 19.80 and molecular weight 254, compound is Octadecane $\left(\mathrm{C}_{18} \mathrm{H}_{38}\right)$, retention time 20.97 and molecular weight 268 ,compound is Nonadecane, $\left(\mathrm{C}_{19} \mathrm{H}_{40}\right)$, retention time 22.12 and molecular weight 282, compound is Eicosane, $\left(\mathrm{C}_{20} \mathrm{H}_{42}\right)$, retention time 23.30 and molecular weight 296, compound is Heneicosane, $\left(\mathrm{C}_{21} \mathrm{H}_{44}\right)$, retention time 25.75 and molecular weight 394, compound is Octacosane, $\left(\mathrm{C}_{28} \mathrm{H}_{58}\right)$ and ultimately retention time 27.06 and molecular weight 380 , compound is Heptacosane, $\left(\mathrm{C}_{27} \mathrm{H}_{56}\right)$ etc.

Table 4. FT-IR spectrum of proportional waste plastic to fuel functional group

\begin{tabular}{|c|c|c|c|c|c|}
\hline Number of Wave & $\begin{array}{c}\text { Wave Number } \\
\left(\mathrm{cm}^{-1}\right)\end{array}$ & Functional Group Name & $\begin{array}{c}\text { Number of } \\
\text { Wave }\end{array}$ & $\begin{array}{c}\text { Wave Number } \\
\left(\mathrm{cm}^{-1}\right)\end{array}$ & Functional Group Name \\
\hline 2 & 3077.91 & H Bonded NH & 18 & 1631.40 & Non-Conjugated \\
\hline 3 & 2936.32 & $\mathrm{C}-\mathrm{CH}_{3}$ & 19 & 1603.83 & Conjugated \\
\hline 4 & 2729.80 & $\mathrm{C}-\mathrm{CH}_{3}$ & 22 & 1440.16 & $\mathrm{CH}_{2}$ \\
\hline 5 & 2671.87 & $\mathrm{C}-\mathrm{CH}_{3}$ & 23 & 1377.41 & $\mathrm{CH}_{3}$ \\
\hline 8 & 2185.74 & $\mathrm{C}-\mathrm{C}=-\mathrm{C}-\mathrm{C}$ & 29 & 1029.91 & Secondary Cyclic Alcohol \\
\hline 11 & 1870.93 & Non-Conjugated & 30 & 1020.53 & Acetates \\
\hline 12 & 1816.65 & Non-Conjugated & 31 & 989.91 & $-\mathrm{CH}=\mathrm{CH}_{2}$ \\
\hline 13 & 1797.55 & Non-Conjugated & 32 & 965.28 & $-\mathrm{CH}=\mathrm{CH}-(\operatorname{trans})$ \\
\hline 14 & 1742.17 & Non-Conjugated & 33 & 909.21 & $-\mathrm{CH}=\mathrm{CH}_{2}$ \\
\hline 15 & 1720.87 & Non-Conjugated & 36 & 728.08 & $-\mathrm{CH}=\mathrm{CH}-(\mathrm{cis})$ \\
\hline 16 & 1684.15 & Conjugated & 37 & 697.90 & $-\mathrm{CH}=\mathrm{CH}-(\mathrm{cis})$ \\
\hline 17 & 1642.02 & Conjugated & & & \\
\hline
\end{tabular}




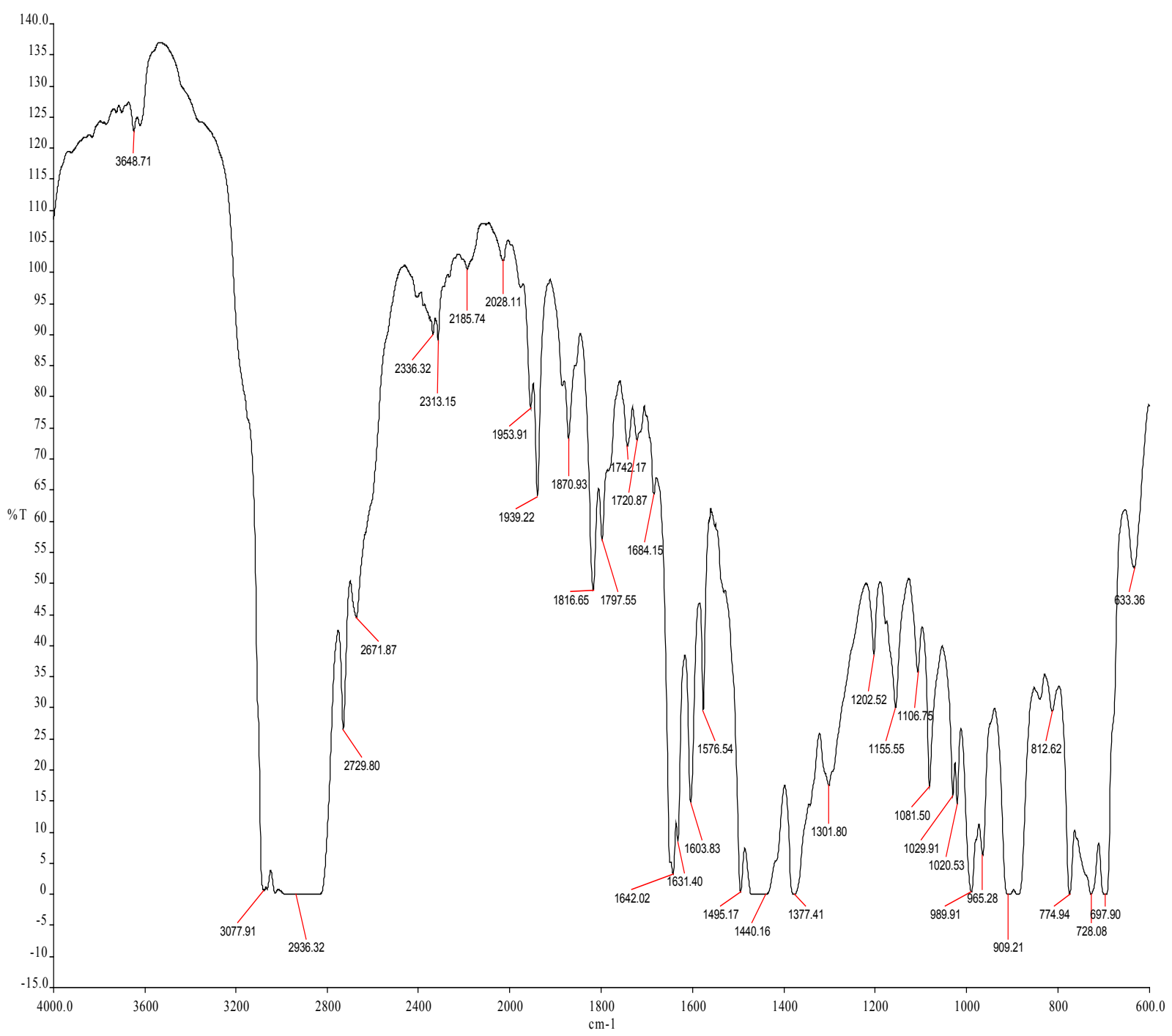

Figure 3. FT-IR spectrum of proportional waste plastics to fuel

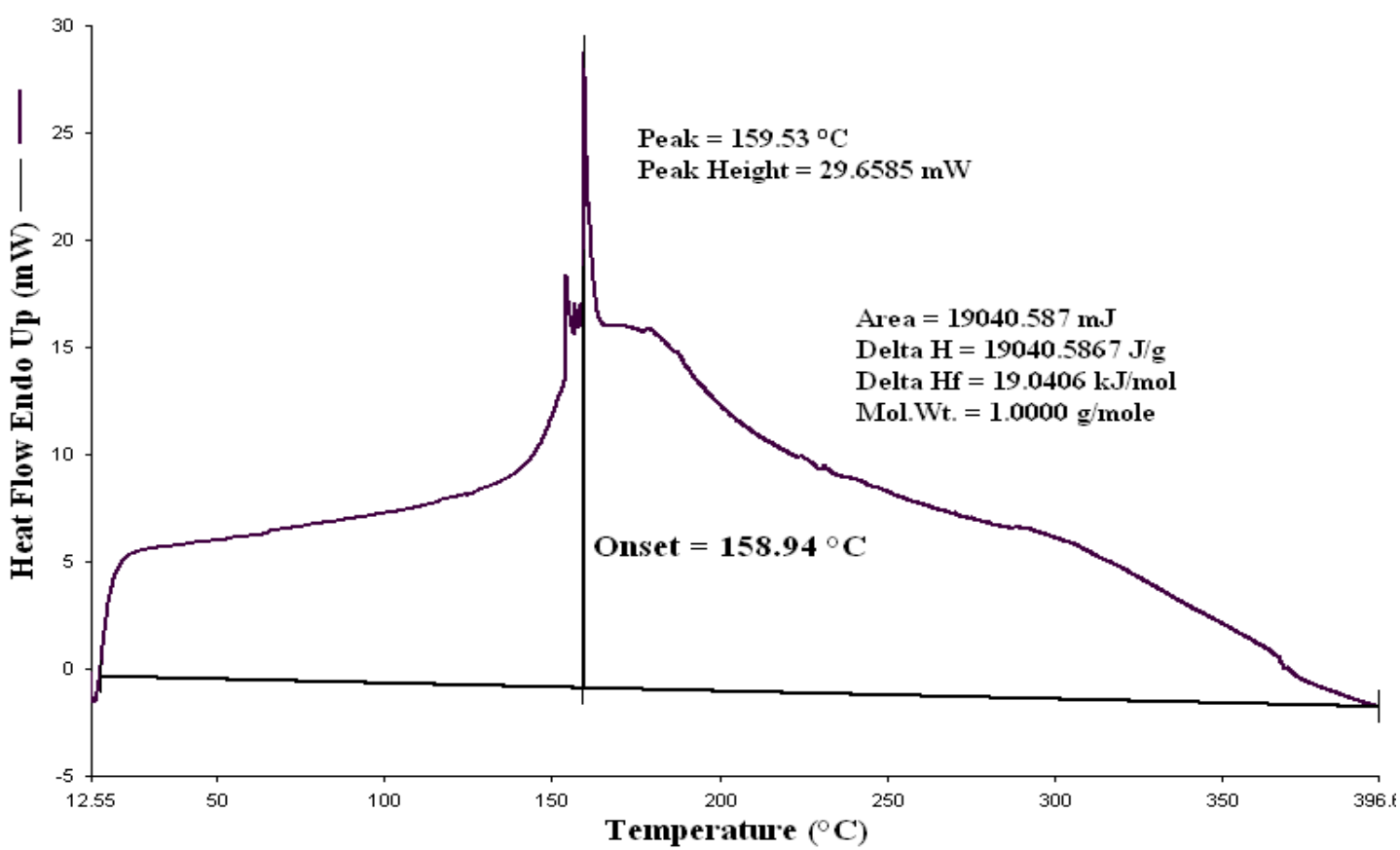

Figure 4. DSC graph of proportional waste plastics into fuel 
After fuel sample analysis by FT-IR (Spectrum 100) was found some functional group seen fig.3 and table 4. From FT-IR fuel spectrum showed alkane, alkene and alkyne group are present. FT-IR analysis traces following types of functional group are found such as wave number 3077.91 $\mathrm{cm}^{-1}$, functional group is $\mathrm{H}$ bonded $\mathrm{NH}$, ascending wave number $2936.32 \mathrm{~cm}^{-1}, \quad 2729.80 \quad \mathrm{~cm}^{-1}, \quad 2671.87$ $\mathrm{cm}^{-1}$,functional group is $\mathrm{C}-\mathrm{CH}_{3}$. Again several wave number same as following ascending way suppose 1870.93 $\mathrm{cm}^{-1}, 1816.65 \mathrm{~cm}^{-1}, 1797.55 \mathrm{~cm}^{-1}, 1742.17 \mathrm{~cm}^{-1}, 1720.87$ $\mathrm{cm}^{-1}, 1631.40 \mathrm{~cm}^{-1}$ compound is Non-Conjugated, then wave number $1684.15 \mathrm{~cm}^{-1}$ and $1642.02 \mathrm{~cm}^{-1}, 1603.83 \mathrm{~cm}^{-1}$ compound is Conjugated. Subsequently wave/frequency number $1440.16 \mathrm{~cm}^{-1}$, compound is $\mathrm{CH}_{2}$, wave number $1377.41 \mathrm{~cm}^{-1}$ functional group is $\mathrm{CH}_{3}$, wave nu mber 1029.91 $\mathrm{cm}^{-1}$,compound is Secondary Cyclic Alcohol, wave number $1020.53 \mathrm{~cm}^{-1}$,functional group is Acetates. Again iteratively wave number $989.91 \mathrm{~cm}^{-1}$ and $909.21 \mathrm{~cm}^{-1}$ wave functional group is $-\mathrm{CH}=\mathrm{CH}_{2}$ and following way wave number 965.28 $\mathrm{cm}^{-1}$,functional group is $-\mathrm{CH}=\mathrm{CH}-($ trans) and finally wave number $728.08 \mathrm{~cm}^{-1}$ and $697.90 \mathrm{~cm}^{-1}$ functional group is $-\mathrm{CH}=\mathrm{CH}-$ (cis) respectively.

Table 5. Liquid fuel analysis of AST M test result

\begin{tabular}{|c|c|c|c|}
\hline Name of Meth od & Test Name & Results & Units \\
\hline AST M D240 & Gross Heat of Combustion & 19118 & BTU/lb \\
\hline AST M D240 & Gross Heat of Combustion (Calculated) & 129142 & BTU/gal \\
\hline AST M D4052 & API Gravity@60F & 42.9 & ${ }^{\circ} \mathrm{API}$ \\
\hline AST M D86-07b & IBP Recovery & 75.6 & ${ }^{\circ} \mathrm{C}$ \\
\hline AST M D86-07b & $5 \%$ Recovery & 110.0 & ${ }^{\circ} \mathrm{C}$ \\
\hline AST M D86-07b & $10 \%$ Recovery & 122.8 & ${ }^{\circ} \mathrm{C}$ \\
\hline AST M D86-07b & $20 \%$ Recovery & 138.9 & ${ }^{\circ} \mathrm{C}$ \\
\hline AST M D86-07b & $30 \%$ Recovery & 153.3 & ${ }^{\circ} \mathrm{C}$ \\
\hline AST M D86-07b & $40 \%$ Recovery & 168.9 & ${ }^{\circ} \mathrm{C}$ \\
\hline AST M D86-07b & $50 \%$ Recovery & 200.0 & ${ }^{\circ} \mathrm{C}$ \\
\hline AST M D86-07b & $60 \%$ Recovery & 240.0 & ${ }^{\circ} \mathrm{C}$ \\
\hline AST M D86-07b & $70 \%$ Recovery & 273.3 & ${ }^{\circ} \mathrm{C}$ \\
\hline AST M D86-07b & $80 \%$ Recovery & 301.1 & ${ }^{\circ} \mathrm{C}$ \\
\hline AST M D86-07b & $90 \%$ Recovery & 335.6 & ${ }^{\circ} \mathrm{C}$ \\
\hline AST M D86-07b & $95 \%$ Recovery & 368.9 & ${ }^{\circ} \mathrm{C}$ \\
\hline AST M D86-07b & Recovery & 96.0 & Vol\% \\
\hline AST M D86-07b & Residue & 2.0 & Vol\% \\
\hline AST M D86-07b & Total recovery & 96.0 & Vol\% \\
\hline AST M D86-07b & Loss & 2.0 & Vol\% \\
\hline AST M D2500 & Automatic Cloud point & 10.9 & ${ }^{\circ} \mathrm{C}$ \\
\hline AST M D2500 & Cloud Point & 51.6 & ${ }^{\circ} \mathrm{F}$ \\
\hline AST M D97 & Pour point & 8 & ${ }^{\circ} \mathrm{C}$ \\
\hline AST M D97 & Pour point & 46.4 & ${ }^{\circ} \mathrm{F}$ \\
\hline AST M D2386 & Freezing Point & 10.0 & ${ }^{\circ} \mathrm{C}$ \\
\hline AST M D2386 & Freezing Point & 50 & ${ }^{\circ} \mathrm{F}$ \\
\hline AST M D2624 & Temperature & 23.3 & ${ }^{\circ} \mathrm{C}$ \\
\hline AST M D2624 & Electrical Conductivity & 6 & $\mathrm{pS} / \mathrm{M}$ \\
\hline AST M D5453 & Sulfur & 2.3 & $\mathrm{Mg} / \mathrm{kg}$ \\
\hline AST M D1 500 & AST M Color & $<4.5$ & \\
\hline AST M D4 176 & Appearance: Clean and Bright & Pass & \\
\hline AST M D4 176 & Special Observation & No Special Observations & \\
\hline AST M D4737 & Cetane Index by D4737 (Procedure A) & 41.8 & \\
\hline AST M D5708_MOD & Vanadium & $<1.00$ & ppm \\
\hline AST M D5708_MOD & Nickel & $<1.00$ & ppm \\
\hline AST M D5708_MOD & Iron & $<1.00$ & ppm OR, mg/Kg \\
\hline AST M D482 & Average Ash & $<0.001$ & $\mathrm{Wt} \%$ \\
\hline AST M D93 & Procedure Used & & \\
\hline AST M D93 & Corrected Flash Point & Below Room Temperature & ${ }^{\circ} \mathrm{C}$ \\
\hline AST M D4530 & $\begin{array}{c}\text { Average Micro Method Carbon Residue } 10 \% \\
\text { distillation }\end{array}$ & 0.3 & $\mathrm{Wt} \%$ \\
\hline AST M D664 & Procedure Used & & \\
\hline AST M D664 & Acid Number & $<0.10$ & $\mathrm{mgKOH} / \mathrm{gm}$ \\
\hline AST M D130 & Copper Corrosion @ $50^{\circ} \mathrm{C}\left(122^{\circ} \mathrm{F}\right) / 3$ hrs. & $1 \mathrm{a}$ & \\
\hline AST M D2709 & Sediment and $\mathrm{W}$ ater & 0.005 & Vol\% \\
\hline AST M D5291 & Carbon Content & 87.30 & $\mathrm{Wt} \%$ \\
\hline AST M D5291 & Hydrogen Content & 12.53 & $\mathrm{Wt} \%$ \\
\hline AST M D5291 & Nitrogen Content & $<0.75$ & $\mathrm{Wt} \%$ \\
\hline
\end{tabular}


Table 6. Solid black residue analysis result by ICP

\begin{tabular}{|c|c|c|c|c|c|}
\hline Test Me thod Name & $\begin{array}{l}\text { Metal } \\
\text { Name }\end{array}$ & $\begin{array}{l}\text { Results } \\
\text { ( ppm) }\end{array}$ & Test Me thod Name & $\begin{array}{l}\text { Metal } \\
\text { Name }\end{array}$ & $\begin{array}{c}\text { Results } \\
\text { ( ppm) }\end{array}$ \\
\hline \multirow[t]{14}{*}{ AST M D1976 } & & & AST M D1976 & & \\
\hline & Aluminium & 1,517 & & Magnesium & 1,480 \\
\hline & Arsenic & 24.5 & & Manganese & 8.8 \\
\hline & Antimony & $<1.0$ & & Nickel & 11.9 \\
\hline & Boron & 3.3 & & Potassium & 127.7 \\
\hline & Barium & 11.8 & & Sodium & 213.4 \\
\hline & Beryllium & $<1.0$ & & Silver & $<1.0$ \\
\hline & Calcium & 134,300 & & Selenium & $<1.0$ \\
\hline & Cadmium & $<1.0$ & & Silicon & 8.4 \\
\hline & Chromium & 4.0 & & Tin & 273.7 \\
\hline & Copper & 3.8 & & Titanium & 558.4 \\
\hline & Iron & 538.7 & & Vanadium & $<1.0$ \\
\hline & Lead & $<1.0$ & & Zinc & 433.3 \\
\hline & Lithium & 29.3 & & & \\
\hline
\end{tabular}

Table 7. Carbon, Hydrogen and Nitrogen percentage into solid residue by EA-2400 (CHN mode)

\begin{tabular}{ccccc}
\hline Name of Meth od & Name of Sample & Carbon \% & Hydrogen \% & Nitrogen \% \\
\hline ASTM D5291.a & Solid black residue & 56.51 & 0.95 & $<0.30$ \\
\hline
\end{tabular}

In accordance with some functional group were calculated energy value of each band of derived compound such as for $\mathrm{H}$ bonded $\mathrm{NH}$, energy value is $6.11 \times 10^{-20} \mathrm{~J}$, for $\mathrm{C}-\mathrm{CH}_{3}$ energy value is $5.83 \times 10^{-20} \mathrm{~J}$, for $\mathrm{C}-\mathrm{C}=--\mathrm{C}-\mathrm{C}$ energy value is $2.04 \times 10^{-20} \mathrm{~J}$, for Non-Conjugated energy value is $3.71 \times 10^{-20}$ $\mathrm{J}$ and for compound $-\mathrm{CH}=\mathrm{CH}-$ (cis) energy value is $1.44 \times 10-{ }^{20} \mathrm{~J}$ respectively. Euclidean Search Hit List: 0.456 F91080 TRICHLOROACETONITRILE, 0.448 F37460 2,5-DIHYDROXYACETOPHENONE, $0.366 \quad$ F65155 2-METHOXYPHENYLACETONITRILE, 0.356 F65470 3-METHYLA CETOPHENONE, 0.327 F54150 2-HYDRO XYACETOPHENONE, 0.295 F22850 4-CHLOROACETO PHENONE, 0.292 F64700 2-METHOXYA CETOPHENO NE, 0.272 F00508 ETHYL ACETOHYDROXAMATE, 0.262 F38558 3,4-DIMETHOXYA CETOPHENONE, 0.229 F65156 3-METHOXYPHENYLA CETONITRILE, (Perkin Elmer FT-IR tutorial library).

For proportional waste plastic to fuel analys is purpose was use DSC equip ment for measuring boiling point temperature and enthalpy value (fig.4). For fuel analys is purpose was used Nitrogen $\left(\mathrm{N}_{2}\right)$ gas as a carrier. Program setup was initial temperature $10^{\circ} \mathrm{C}$ and height $400^{\circ} \mathrm{C}$ and te mperature ra mp ing rate was per minute $10^{\circ} \mathrm{C}$. After fuel analys is found some information such as onset temperature $158.94^{\circ} \mathrm{C}$, peak temperature $159.5^{\circ} \mathrm{C}$, peakheight $29.6585 \mathrm{~mW}$ and enthalpy delta $\mathrm{H}$ is $19040.5867 \mathrm{~J} / \mathrm{g}$.

ASTM test also performed according to standard method as follows such as API Gravity@60 ${ }^{\circ} \mathrm{F}$ (ASTM D4052), Barometric Pressure (ASTM D86), ASTM color (ASTM D1500), metal analysis (ASTM D5708), Ash@775 ${ }^{\circ} \mathrm{C}$ (ASTM D482) etc showed table 5, solid black residue ICP analysis result showed table 6 and black residue carbon, hydrogen and nitrogen percentage showed table 7 .

\section{Conclusions}

Waste plastic are major problem for environment. Waste plastics are releasing gas emission into environment because waste plastic are not bio degradable. This waste plastic can remain long period in landfill. The thermal degradation process applied with mixture waste plastics of high density polyethylene (HDPE), low density polyethylene (LDPE), Polypropylene (PP) and Polystyrene (PS) using stainless steel reactor with activated carbon. The polymer has been selected for the experiment $25 \%$ each of HDPE, LDPE, PP and PS by weight. The temperature used for thermal degradation at $25-420^{\circ} \mathrm{C}$. The obtained products are liquid fuel, light gas and black carbon solid residue. Various technique (Gas Chromatography and Mass Spectrometer, FT-IR and DSC) are used for produced fuel analys is. GC/MS result is showing hydrocarbon compound ranges fro $\mathrm{m} \mathrm{C}_{3}-\mathrm{C}_{28}$ and light gas are present $\mathrm{C}_{1}-\mathrm{C}_{4}$. Using activated carbon with waste plastic its removing plastic dye from fuel, this activated used as filtered. Activated carbon is seated with black residue end of the experiment is not come out with liquid fuel. Activated carbon using with this experiment fuel is clean and color is bright yellow. This fuel burns cleaner and burning time is also longer.

\section{ACKNOWLEDGEMENTS}

The author acknowledges the support of Dr. Karin Kaufman, the founder and sole owner of Natural State Research, Inc.,(NSR). The author also acknowledges the valuable contributions NSR laboratory tea m members during the preparation of this manuscript. 


\section{REFERENCES}

[1] Plastic Wastes: Resource Recovery and Recycling in Japan. Tokyo: Plastic Waste Management Institute, 1985.

[2] Andrews GD, Subramanian PM, editors. Emerging Technologies in Plastics Recycling. ACS Symp Ser 513. Washington, DC: 1992.

[3] Curlee TR, Das S. Identify ing and assessing of opportunity for plastics recycling. Resourc Conserv Recycl 1991; 5:343-63.

[4] Yakowitz H. Incineration of MSW: scientific and technical evaluation of the state-of the-art by an expert panel. Resourc Conserv Recycl 1990; 4:241-51.

[5] Bennett RA. Recycled plastics: product applications and potential. In: Andrews GD, Subramanian PM, editors. Emerging Technologies in Plastics Recycling. ACS Symp Ser 513. Washington, DC: 1992:26-38.

[6] Bahr A. The sorting of plastic wastes. In: Thome-Kozmiensky KJ, editor. International Recycling Congress, Berlin, 1979. Berlin: Freitag Verlag, 1979: $1202-1210$

[7] A.G. Buekens *, H. Huang, Catalytic plastics cracking for recovery of gasoline-range hydrocarbons from municipal plastic wastes, Resources, Conservation and Recycling 23 (1998) 163-181.

[8] J. Aguado*, D. P. Serrano and J. M. Escola" Fuels from Waste Plastics by Thermal and Catalytic Processes: A Review" Ind. Eng. Chem. Res. 2008, 47, 7982-7992

[9] Masamichi Akimoto*, Toshifumi Sato, and Tatsuro Nagasawa " Hydrothermal Denitrogenation of Fuel Oil Derived from Municipal Waste Plastics in a Continuous

Packed-Bed Reactor" Ind. Eng. Chem. Res. 2003, 42, 2074-2080

[10] Yongsangkim*, Youngseokkim and Sunghyunkim " Investigation of Thermodynamic Parameters in the Thermal Decomposition of Plastic Waste-Waste Lube Oil Compounds " Environ. Sci. Technol. 2010, 44, 5313-5317

[11] Jose M. Arandes, ${ }^{*}$ Javier Erena, and Javier Bilbao "Valorization of Polyolefins Dissolved in Light Cycle Oil over HY Zeolites under Fluid Catalytic Cracking Unit Conditions" Ind. Eng. Chem. Res. 2003, 42, 3952-3961

[12] George Manos*, Arthur Garforth and John Dwyer " Catalytic Degradation of High-Density Polyethylene over Different Zeolitic Structures" Ind. Eng. Chem. Res. 2000, 39, 1198-1202

[13] George Manos*, Isman Y. Yusof, Nikos Papayannakos and Nicolas H. Gangas " Cataly tic Cracking of Poly ethylene over Clay Catalysts. Comparison with an Ultrastable Y Zeolite" Ind. Eng. Chem. Res. 2001, 40, 2220-2225

[14] A. Marcilla*, M. I. Beltran, and R. Navarro " Evolution with the Temperature of the Compounds Obtained in the Catalytic Py roly sis of Poly ethy lene over HUSY" Ind. Eng. Chem. Res. 2008, 47, 6896-6903

[15] R. W. J. Westerhout, J. Waanders, J. A. M. Kuipers, * and W. P. M. van Swaaij " Recycling of Poly ethene and Polypropene in a Novel Bench-Scale Rotating Cone Reactor by High-Temperature Pyroly sis " Ind. Eng. Chem. Res. 1998, 37, 2293-2300

[16] Ahmad Rahman Songip, Takao Masuda, Hiroshi Kuwahara and Kenji Hashimoto* " Kinetic Studies for Catalytic Cracking of Heavy Oil from Waste Plastics over REY Zeolite" Energy \& Fuels 1994, 8, 131-135

[17] Tullo, A. H. Plastic additives. Chem. Eng. News 2003, 81 (46), 36-42. 